\title{
Influence of Nitrogen Fertilizer and Foliar Application of Salicylic Acid on Wheat
}

\author{
Omar Maghawry Ibrahim 1*, Ahmed Bakry Bakry2, Alice Tawfeek Thalooth², \\ Mohamed Farouk El-Karamany ${ }^{2}$ \\ ${ }^{1}$ Plant Production Department, Arid Lands Cultivation Research Institute, City of Scientific Research and \\ Technological Applications (SRTA-City), New Borg El-Arab, Alexandria, Egypt \\ ${ }^{2}$ Field Crops Research Department, National Research Centre, Giza, Egypt \\ Email: dromarnrc@gmail.com
}

Received 29 September 2014; revised 28 October 2014; accepted 16 November 2014

Copyright @ 2014 by authors and Scientific Research Publishing Inc.

This work is licensed under the Creative Commons Attribution International License (CC BY).

http://creativecommons.org/licenses/by/4.0/

(c) (i) Open Access

\section{Abstract}

Two cemented plots experiments were carried out during the winter seasons of 2012/2013 and 2013/2014, Soil Salinity Laboratory, Alexandria, Egypt, to study the effect of three levels of salicylic acid (SA) $(0,50,100 \mathrm{ppm})$ and three rates of nitrogen fertilizer $(75,100,125 \mathrm{~kg} \mathrm{~N} /$ feddan) on yield and yield components of wheat (Sakha 93). The experimental design was split plot with four replicates. The results indicated that increasing nitrogen fertilizer rates resulted in significant increase in plant height $(\mathrm{cm})$, number of grain/spike, number of spikes $/ \mathrm{m}^{2}, 1000$ grain weight (gm), grain yield (gm/plot), straw yield (gm/plot), and biological yield (gm/plot). Increasing salicylic acid rates resulted in significant increase in all the previous characters, in addition to grain weight/spike (gm). The interactions had no significant effect on the studied characters. The path analysis revealed that $\mathbf{1 0 0 0}$ grain weight was the most important character with direct effect of 0.54 followed by number of spikes $/ \mathrm{m}^{2}$ with direct effect of 0.33 followed by number of grain/spike with direct effect of 0.16 .

\section{Keywords}

Wheat, Salicylic Acid, Nitrogen Fertilizer, Path Analysis

\section{Introduction}

Wheat (Triticum aestivum L.) is considered one of the most important cereal crops not only in Egypt but also in the world. Its importance comes from using its grain as a main food source for human and its straw as feed for

\footnotetext{
${ }^{*}$ Corresponding author.
}

How to cite this paper: Ibrahim, O.M., Bakry, A.B., Thalooth, A.T. and El-Karamany, M.F. (2014) Influence of Nitrogen Fertilizer and Foliar Application of Salicylic Acid on Wheat. Agricultural Sciences, 5, 1316-1321. 
livestock. As land and water resources are limited in Egypt, increasing the productivity of wheat from the unit area is an important part in increasing the total production and minimizes the gap between consumption and production. Such target will be achieved by increasing the cultivated area, cultivating high yield varieties, and adoption of improved cultural practices.

Salicylic acid (SA) is a phenolic compound naturally produced by the plants and function as growth regulator [1]. Exogenous application of SA may influence some physiological processes, e.g., growth and photosynthesis [2]-[4]. Photosynthesis plays an important role in plant productivity and takes place in green leaves and depends on its content of chlorophyll. [5] found that maize cultivars that maintained higher rates of photosynthesis produced higher grain yield, also, these cultivars had higher stomatal conductance, transpiration rate and leaf area. Thus, the biological and economic yield can be increased by increasing the rate of photosynthesis. In this respect [6] recorded an increase in wheat yield by exogenous application of SA, also, [7] [8] recorded similar results in corn. [9] reported also that SA reversed the closure of stomata caused by abscisic acid which induced by abiotic stresses like salinity and draught.

Nitrogen fertilizer has been extensively used in agriculture in recent years, however, the intensive using of nitrogen fertilizers have hazard effect on the environment [10] in addition to decreasing the net profit per unit area as the prices of inputs increased. Thus, in response of all afore-mentioned reports, the present study was conducted to investigate the effect of foliar application of SA and three rates of nitrogen fertilizer on the productivity of wheat plants cultivar (Sakha 93).

\section{Materials and Methods}

Grain of wheat cultivar Sakha 93 was obtained from Crops Research Institute, Agricultural Research Center, Egypt. The experiment was conducted during the winter seasons of 2012/2013 and 2013/2014 to investigate the effect of three levels of SA (0, 50, $100 \mathrm{ppm})$ and nitrogen fertilizer rates $(75,100,125 \mathrm{~kg}$ N/feddan) on yield and yield components. The experimental soil was analyzed according to [11] before sowing and the mechanical and chemical characters in both seasons are presented in Table 1.

The experimental design was split plot with four replicates where the nitrogen fertilizer rates were located in the main plot, while SA rates were in the subplot, the experimental unit was a cemented plot with a dimension of $150 \mathrm{~cm}$ in long and $75 \mathrm{~cm}$ in wide with an area of $1.125 \mathrm{~m}^{2}$. Every cemented plot contains four rows, the grain were sowing in mid-November in each year and before sowing the cemented plot were prepared by adding calcium superphosphate $15.5 \% \mathrm{P}_{2} \mathrm{O}_{5}$ at a rate of $100 \mathrm{~kg} /$ feddan $(26.78 \mathrm{gm} /$ cemented plot) and potassium sulphate $48 \% \mathrm{~K}_{2} \mathrm{O}$ at a rate of $100 \mathrm{~kg} / \mathrm{feddan}(13.39 \mathrm{gm} / \mathrm{cemented} \mathrm{plot})$, the nitrogen fertilizer rates were added at the rate of $75,100,125 \mathrm{~kg} \mathrm{~N} /$ feddan ) of ammonium sulphate $20.5 \% \mathrm{~N}(98,130.7,163.4 \mathrm{gm} / \mathrm{cemented}$ plot at three doses, the first at sowing, the second at the first irrigation, and the third at the second irrigation).

SA was initially dissolved in a few drops of Dimethylsulfoxide and the final volume was reached by adding distilled water, then the $\mathrm{pH}$ was adjusted at $6-7$ with $\mathrm{NaOH}(1.0 \mathrm{~N})$. A constant volume of solutions were sprayed twice early in the morning on the leaves when the plants had their fourth leaf and two weeks later.

At the end of the experiment random samples were taken to measure the following characters:

Plant height (cm), spike weight (gm), number of grain/spike, number of grain/spike, grain weight/spike (gm), number of spikes $/ \mathrm{m}^{2}$, number of spikelets/spike, 1000 grain weight (gm), grain yield (gm/cemented plot), biological yield (gm/cemented plot), straw yield (gm/cemented plot), harvest index as the ratio between grain yield and biological yield.

A combined analysis was conducted as the Bartlete test for homogeneity of variance revealed that the variances of the studied characters of the two seasons were homogeneous, the data of the two seasons were subjected to analysis of variance using SAS computer software v.9.1.3 SP4, 2003. The mean values were compared with the least significant difference test according to [12].

Table 1. Physical and chemical analyses of the used soil.

\begin{tabular}{cccccccccccccc}
\hline $\begin{array}{c}\text { Sand } \\
\%\end{array}$ & $\begin{array}{c}\text { Silt } \\
\%\end{array}$ & $\begin{array}{c}\text { Clay } \\
\%\end{array}$ & $\begin{array}{c}\text { Soil } \\
\text { texture }\end{array}$ & $\begin{array}{c}\text { E.C. } \\
\mathrm{dS} / \mathrm{m}\end{array}$ & $\mathrm{pH}$ & $\mathrm{SAR}$ & $\begin{array}{c}\mathrm{Ca}^{2+} \\
\mathrm{meq} / \mathrm{l}\end{array}$ & $\begin{array}{c}\mathrm{Mg}^{2+} \\
\mathrm{meq} / \mathrm{l}\end{array}$ & $\begin{array}{c}\mathrm{Na}^{+} \\
\mathrm{meq} / \mathrm{l}\end{array}$ & $\begin{array}{c}\mathrm{K}^{+} \\
\mathrm{meq} / \mathrm{l}\end{array}$ & $\begin{array}{c}\mathrm{Cl}^{-} \\
\mathrm{meq} / \mathrm{l}\end{array}$ & $\begin{array}{c}\mathrm{HCO}_{3}^{-} \\
\mathrm{meq} / \mathrm{l}\end{array}$ \\
\hline 74.0 & 10.4 & 15.6 & Sandy loam & 1.82 & 7.53 & 1.49 & 1.50 & 12.5 & 3.95 & 0.34 \\
\hline
\end{tabular}




\section{Results and Discussions}

\subsection{Effect of Nitrogen Fertilizer Rates}

Table 2 shows that with increasing the nitrogen fertilizer rates plant height, Number of grain/spike and number of grain/spike significantly increased, but, spike weight had no specific trend or significant differences. In addition, grain weight/spike insignificantly increased with increasing nitrogen fertilizer rates. Table 3 indicates that increasing nitrogen fertilizer rates resulted in significant increase in number of spikes $/ \mathrm{m}^{2}, 1000$ grain weight, grain yield, straw yield, and biological yield. However, no significant difference was observed in number of spikelets/spike and harvest index.

\subsection{Effect of Salicylic Acid}

Table 2 indicates that exogenous application of SA significantly increased plant height, Number of grain/spike, number of grain/spike, and grain weight/spike. Spike weight was also not significantly affected by SA. These results are consistent with those obtained by [13] who reported similar increase in the growth of shoots of soybean plants in response to salicylic acid treatment. Also, [14] [15] indicate that SA increases the leaf area in sugar cane plants. [16] recorded significant increase in Emergence index (EI), leaf area (LI), dry weight of leaves and crown, leaves and tillers number and shoot apex length than untreated or control treatments. The highest enhancement in mentioned traits was observed in concentrations of $1000 \mu \mathrm{M}$ and $1500 \mu \mathrm{M}$. More recently [17] also reported that salicylic acid spraying affect morphological traits and resulted in considerable and

Table 2. Effect of nitrogen fertilizer rates and salicylic acid on plant height and spike characters of wheat plants (combined analysis of the two seasons).

\begin{tabular}{|c|c|c|c|c|c|}
\hline & $\begin{array}{c}\text { Plant height, } \\
\mathrm{cm}\end{array}$ & $\begin{array}{l}\text { Spike weight, } \\
\text { gm }\end{array}$ & $\begin{array}{l}\text { Spike length, } \\
\mathrm{cm}\end{array}$ & $\begin{array}{l}\text { Number of } \\
\text { grain/spike }\end{array}$ & $\begin{array}{c}\text { Grain weight/spike, } \\
\text { gm }\end{array}$ \\
\hline & \multicolumn{5}{|c|}{ Nitrogen fertilizer rates } \\
\hline $75 \mathrm{~kg} \mathrm{~N} /$ fed & $95.4 \mathrm{~b}$ & $3.2 \mathrm{a}$ & $9.9 \mathrm{~b}$ & $50.5 \mathrm{~b}$ & $2.3 \mathrm{a}$ \\
\hline $100 \mathrm{~kg} \mathrm{~N} /$ fed & $98.8 \mathrm{ab}$ & $2.9 \mathrm{a}$ & $10.0 \mathrm{ab}$ & $53.1 \mathrm{~b}$ & $2.4 \mathrm{a}$ \\
\hline \multirow[t]{2}{*}{$125 \mathrm{~kg} \mathrm{~N} / \mathrm{fed}$} & 100.9 a & $3.2 \mathrm{a}$ & $10.3 \mathrm{a}$ & $57.5 \mathrm{a}$ & 2.6 a \\
\hline & \multicolumn{5}{|c|}{ Salicylic acid } \\
\hline Control & $94.2 \mathrm{c}$ & $3.1 \mathrm{a}$ & $9.6 \mathrm{c}$ & $48.7 \mathrm{c}$ & $2.2 \mathrm{c}$ \\
\hline SA1 (50 ppm) & $97.7 \mathrm{~b}$ & $3.0 \mathrm{a}$ & $10.1 \mathrm{~b}$ & $54.2 \mathrm{~b}$ & $2.4 \mathrm{~b}$ \\
\hline SA2 (100 ppm) & $103.2 \mathrm{a}$ & $3.1 \mathrm{a}$ & $10.6 \mathrm{a}$ & $58.2 \mathrm{a}$ & $2.7 \mathrm{a}$ \\
\hline
\end{tabular}

Table 3. Effect of nitrogen fertilizer rates and salicylic acid on wheat yield and its components (combined analysis of the two seasons).

\begin{tabular}{|c|c|c|c|c|c|c|c|}
\hline & $\begin{array}{l}\text { Number of } \\
\text { spikes } / \mathrm{m}^{2}\end{array}$ & $\begin{array}{c}\text { Number of } \\
\text { spikelets/spike }\end{array}$ & $\begin{array}{l}1000 \text { grain } \\
\text { weight, gm }\end{array}$ & $\begin{array}{c}\text { Grain yield, } \\
\text { gm/plot }\end{array}$ & $\begin{array}{l}\text { Straw yield, } \\
\text { gm/plot }\end{array}$ & $\begin{array}{c}\text { Biological yield, } \\
\text { gm/plot }\end{array}$ & $\begin{array}{r}\text { Harves } \\
\text { index }\end{array}$ \\
\hline & \multicolumn{7}{|c|}{ Nitrogen fertilizer rates } \\
\hline 75 kg N/fed & $226.1 \mathrm{~b}$ & $18.7 \mathrm{a}$ & $43.9 \mathrm{~b}$ & $566.5 \mathrm{~b}$ & $958.6 \mathrm{~b}$ & $1525.2 \mathrm{~b}$ & $0.37 \mathrm{a}$ \\
\hline $100 \mathrm{~kg} \mathrm{~N} /$ fed & $242.4 \mathrm{ab}$ & $18.8 \mathrm{a}$ & $46.0 \mathrm{a}$ & $573.8 \mathrm{ab}$ & $977.4 \mathrm{~b}$ & $1551.3 \mathrm{~b}$ & $0.36 \mathrm{a}$ \\
\hline \multirow[t]{2}{*}{$125 \mathrm{~kg} \mathrm{~N} /$ fed } & $251.0 \mathrm{a}$ & $18.8 \mathrm{a}$ & $46.1 \mathrm{a}$ & 596.8 a & 1039.6 a & $1636.4 \mathrm{a}$ & $0.36 \mathrm{a}$ \\
\hline & \multicolumn{7}{|c|}{ Salicylic acid } \\
\hline Control & $226.0 \mathrm{c}$ & $18.8 \mathrm{a}$ & $43.5 \mathrm{c}$ & $511.2 \mathrm{c}$ & 896.5 c & 1407.7 c & $0.36 \mathrm{a}$ \\
\hline SA1 (50 ppm) & $241.2 \mathrm{~b}$ & 18.7 a & $45.1 \mathrm{~b}$ & $585.0 \mathrm{~b}$ & $985.2 \mathrm{~b}$ & $1570.2 \mathrm{~b}$ & $0.37 \mathrm{a}$ \\
\hline SA2 (100 ppm) & $252.3 \mathrm{a}$ & $18.8 \mathrm{a}$ & $47.5 \mathrm{a}$ & $641.0 \mathrm{a}$ & $1093.9 \mathrm{a}$ & $1734.9 \mathrm{a}$ & $0.37 \mathrm{a}$ \\
\hline
\end{tabular}


significant increase in plant height, ear height, leaf area of the main ear, row no/ear, kern el no/row and ear length of corn plants. Table 3 reveal that exogenous application of 50 and 100 ppm SA resulted in significant increase in number of spikes $/ \mathrm{m}^{2}, 1000$ grain weight, grain yield, straw yield, and biological yield, however, significant difference was observed in number of spikelets/spike and harvest index. It is worth to mention that exogenous application of 50 and $100 \mathrm{ppm}$ of SA caused an increase in grain yield/cemented plot by almost 15\% and 25\% respectively as compared to the control (Figure 1), this increase in grain yield may be attributed to the increase in number of spikes $/ \mathrm{m}^{2}$ and 1000 grain weight. These results were in accordance with those obtained by [18] who reported that application of SA significantly affected seed yield and plant biomass of coriander (Coriandrum sativum).

Finally, it can be concluded that fertilizing wheat with $100 \mathrm{~kg} \mathrm{~N} /$ feddan and application of $100 \mathrm{ppm}$ of SA can produce a reasonable yield.

\subsection{Path Analysis and Correlation between Grain Yield and Yield Components}

All possible correlations among the different yield components were measured (Table 4). Grain yield showed positive and significant correlation with number of grain/spike (0.69), number of spikes $/ \mathrm{m}^{2}$ (0.56), and 1000 grain weight (0.73) which gave an understanding that 1000 grain weight was the most important yield component.

The data of direct effects (Table 5 and Figure 2) and indirect effects (Table 5) of yield components on grain yield revealed that 1000 grain weight had maximum positive direct effect on grain yield $(0.54)$ followed by number of spikes $/ \mathrm{m}^{2}(0.33)$ followed by number of grain/spike (0.16). The results of correlation and path analysis are matching for 1000 grain weight, however, the reverse was the case for the other two components where number of grain/spike was the second correlated components (0.69) and the third in direct effect (0.16), this may be due to the indirect effect of number of spikes $/ \mathrm{m}^{2}$ and 1000 grain weight via number of grain/spike, 0.19 and 0.35 , respectively which was more than the indirect effect of number of grain/spike and 1000 grain weight via number of spikes $/ \mathrm{m}^{2}, 0.09$ and 0.14 , respectively, where the more the indirect effect the less direct effect.

The results of correlation and direct effect of number of spikes $/ \mathrm{m}^{2}$ and 1000 grain weight are agreed with those obtained from [19].

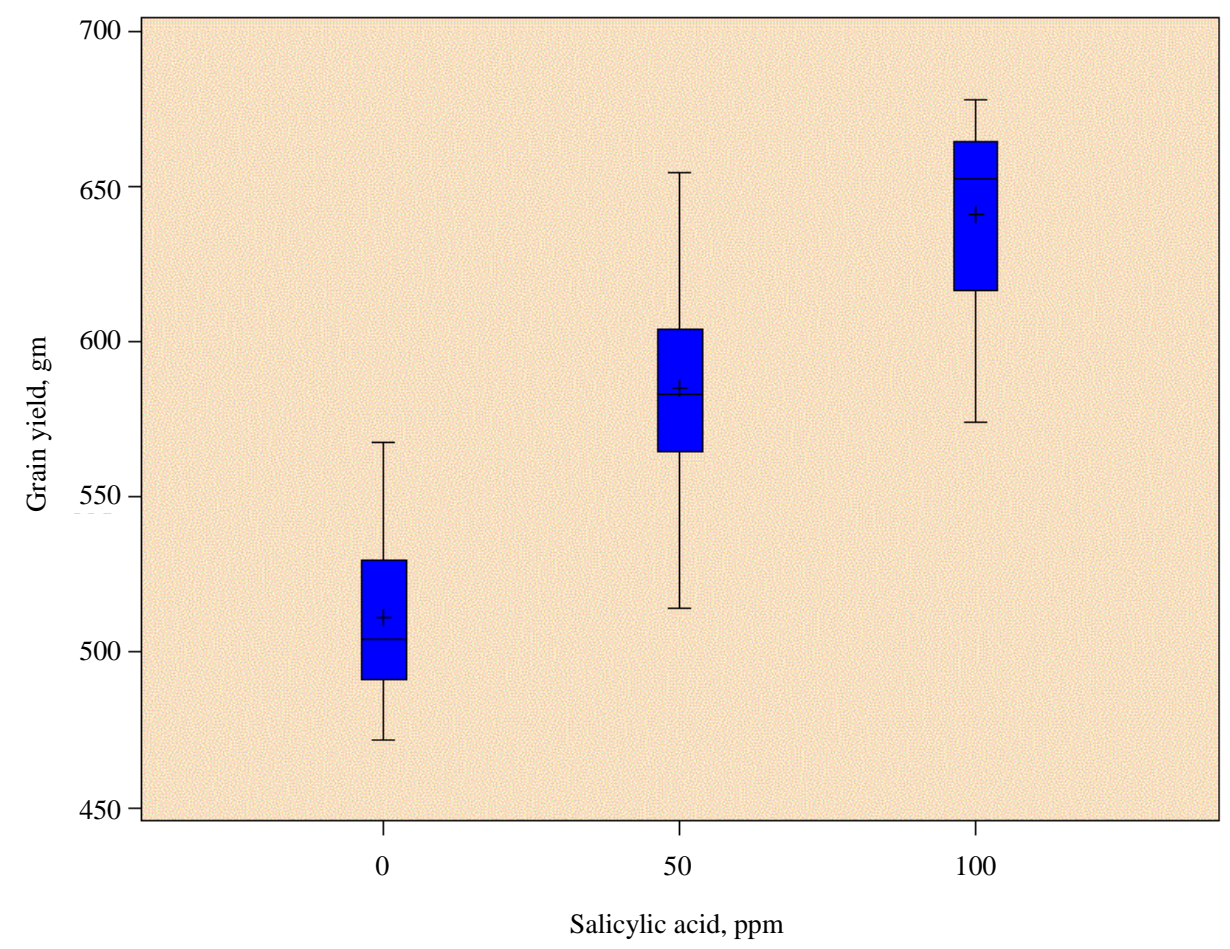

Figure 1. Effect of Salicylic acid on the grain yield of wheat. 
Table 4. Correlation coefficients between yield components and grain yield of wheat.

\begin{tabular}{|c|c|c|c|c|}
\hline & Number of grain/spike & Number of spikes $/ \mathrm{m}^{2}$ & 1000 grain weight, gm & Grain yield, gm/plot \\
\hline Number of grain/spike & 1.00 & & & \\
\hline Number of spikes $/ \mathrm{m}^{2}$ & $0.56^{* *}$ & 1.00 & & \\
\hline 1000 grain weight, gm & $0.64^{* *}$ & $0.26^{\mathrm{ns}}$ & 1.00 & \\
\hline Grain yield, gm/plot & $0.69^{* *}$ & $0.56^{* *}$ & $0.73^{* *}$ & 1.00 \\
\hline
\end{tabular}

${ }^{* *}$ significant at 0.01 significance level; ${ }^{\text {ns }}$ not significant.

Table 5. Direct (underlined) and indirect effects of three yield components on grain yield of wheat.

\begin{tabular}{cccc}
\hline & Number of grain/spike & Number of spikes $/ \mathrm{m}^{2}$ & 1000 grain weight, gm \\
\hline Number of grain/spike & $\underline{\mathbf{0 . 1 6}}$ & 0.19 & 0.35 \\
Number of spikes $/ \mathrm{m}^{2}$ & 0.09 & $\underline{\mathbf{0 . 3 3}}$ & 0.14 \\
1000 grain weight, gm & 0.10 & 0.09 & $\underline{\mathbf{0 . 5 4}}$ \\
\hline
\end{tabular}

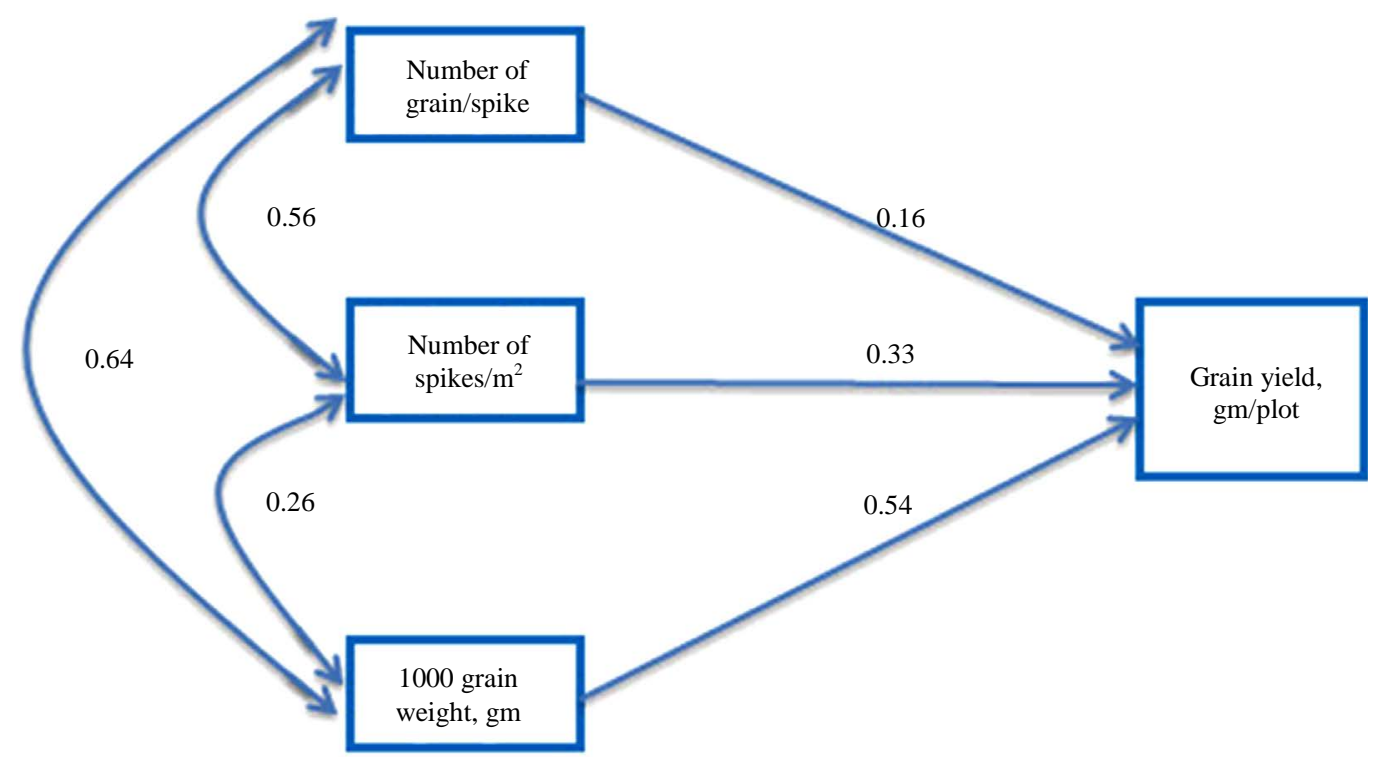

Figure 2. Path diagram and correlation coefficients of three yield components (single headed arrow denotes direct effect on grain yield; double headed arrow denotes the correlation coefficients between traits).

\section{Conclusion}

The current study revealed that both nitrogen fertilizer and salicylic acid were significantly affected yield and its components. The highest effects on yield and its components in wheat were obtained by the level of 125 $\mathrm{kg} /$ feddan of nitrogen fertilizer and $100 \mathrm{ppm}$ of salicylic acid. In conclusion, data indicated that a high yield could be obtained by adding $100 \mathrm{~kg} /$ feddan of nitrogen fertilizer and spraying of $100 \mathrm{ppm}$ of salicylic acid, and suggested that salicylic acid could be used as a potential growth regulator to improve plant growth.

\section{References}

[1] Arberg, B. (1981) Plant Growth Regulators XLI. Mono Substituted Benzoic Acid. Swedish Journal of Agricultural Research, 11, 93-105.

[2] El-Tayeb, M.A. (2005) Response of Barley Grain to the Interactive Effect of Salinity and Salicylic Acid. Plant Growth Regulation, 45, 215-224. http://dx.doi.org/10.1007/s10725-005-4928-1 
[3] Khan, W., Prithiviraj, B. and Smith, D.L. (2003) Photosynthetic Response of Corn and Soybean to Foliar Application of Salicylates. Journal of Plant Physiology, 160, 485-492. http://dx.doi.org/10.1078/0176-1617-00865

[4] Khodary, S.E.A. (2004) Effect of Salicylic Acid on Growth, Photosynthesis and Carbohydrate Metabolism in Salt Stressed Maize Plants. International Journal of Agriculture and Biology, 6, 5-8.

[5] Dong, S.T., Gao, R.Q., Hu, C.H., Wang, Q.Y. and Wang, K.J. (1997) Study of Canopy Photosynthesis Properties and High Yield Potential after Anthesis in Maize. Acta Agronomica Sinica, 23, 318-325.

[6] Lopez, T.R. (1989) Evaluacion de acido salicilico para incrementar numero de granos por espiga yrendimiento entrigo Triticum durum var. Altar c-84, valle del Yaqui, son, tesis de licenciatura. Instituto Tecnologico de Sonora.

[7] Ibrahim, O.M. (2013) A Comparison of Methods for Assessing the Relative Importance of Input Variables in Artificial Neural Networks. Journal of Applied Sciences Research, 9, 5692-5700.

[8] Ibrahim, O.M., Thalooth, A.T. and Badr, E.A. (2013) Application of Self Organizing Map (SOM) to Classify Treatments of the First Order Interaction: A Comparison to Analysis of Variance. World Applied Sciences Journal, 25, 1464-1468.

[9] Rui, V.K., Sharma, S.S. and Sharma, S. (1986) Reversal of ABA-Induced Stomatal Closure by Phenolic Compounds. Journal of Experimental Botany, 37, 129-134. http://dx.doi.org/10.1093/jxb/37.1.129

[10] Badr, E.A., Ibrahim, O.M. and El Kramany, M.F. (2009) Interaction Effect of Biological and Organic Fertilizer on Yield and Yield Components of Two Wheat Cultivars. Egyptian Journal of Agronomy, 31, 17-27.

[11] Jackson, M.L. (1960) Soil Chemical Analysis. Engleweed Cliff, New Jersy, 183-190.

[12] Snedecor, G.W. and Cochran, W.G. (1990) Statistical Methods. 8th Edition, Iowa State University, Ames.

[13] Gutierrez-Coronado, M.A., Trejo-Lopez, C. and Larque-Saavedra, A. (1998) Effects of Salicylic Acid on the Growth of Roots and Shoots in Soybean. Plant Physiology and Biochemistry, 36, 653-665. http://dx.doi.org/10.1016/S0981-9428(98)80003-X

[14] Dhaliwal, R.K., Malik, C.P., Gasal, S.S. and Dhaliwal, L.S. (1997) Studies on Hardening of Micropropagated Sugarcane (Saccharum officinarum L.) Plantlet. Leaf Parameters and Biochemical Estimations. Annals Biology: Ludhiana, 13, 15-20.

[15] Zhou, X.M., Mackenzie, A.F., Madramootoo, C.A. and Smith, D.L.J. (1999) Effects of Some Injected Plant Growth Regulators with or without Sucrose on Grain Production, Biomass and Photosynthesis Activity of Field Grown Corn Plants. Journal of Agronomy and Crop Science, 183, 103-110. http://dx.doi.org/10.1046/j.1439-037x.1999.00331.x

[16] Sanaz, R.Kh., Shekari, F., Sabaand, J. and Esmaiel, Z. (2013) Effects of Salicylic Acid on Emergence and Seedlings Growth of Three Wheat Cultivars under Rainfed Conditions. International Journal of Agronomy and Plant Production, 4, 3057-3062.

[17] Mahdi, Z., Saeid, K.K., Matin. J.M. and Heidarian. A.R. (2013) Effect of Salicylic Acid on Morphological Characteristics, Yield and Yield Components of Corn (Zea mays L.) under Drought Condition. European Journal of Experimental Biology, 3, 153-161.

[18] Sadra, H., Nabizadeh, E., Rahimi, A. and Rokhzadi, A. (2012) Effects of Salicylic Acid Levels and Irrigation Intervals on Growth and Yield of Coriander (Coriandrum sativum) in Field Conditions. Environmental and Experimental Biology, 10, 113-116.

[19] Okuyama, L.A., Federizzi, L.C. and Barbosa, J.F. (2004) Correlation and Path Analysis of Yield and Its Components and Plant Traits in Wheat. Ciencia Rural, 34, 1701-1708. http://dx.doi.org/10.1590/S0103-84782004000600006 
Scientific Research Publishing (SCIRP) is one of the largest Open Access journal publishers. It is currently publishing more than 200 open access, online, peer-reviewed journals covering a wide range of academic disciplines. SCIRP serves the worldwide academic communities and contributes to the progress and application of science with its publication.

Other selected journals from SCIRP are listed as below. Submit your manuscript to us via either submit@scirp.org or Online Submission Portal.
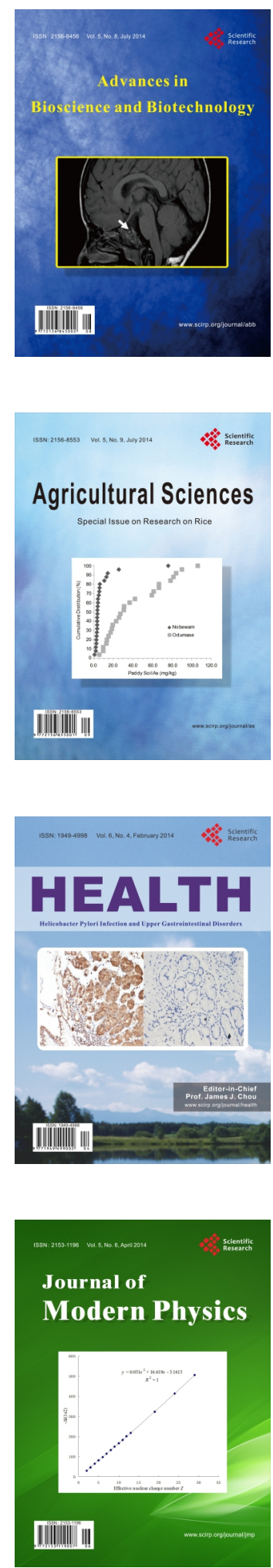
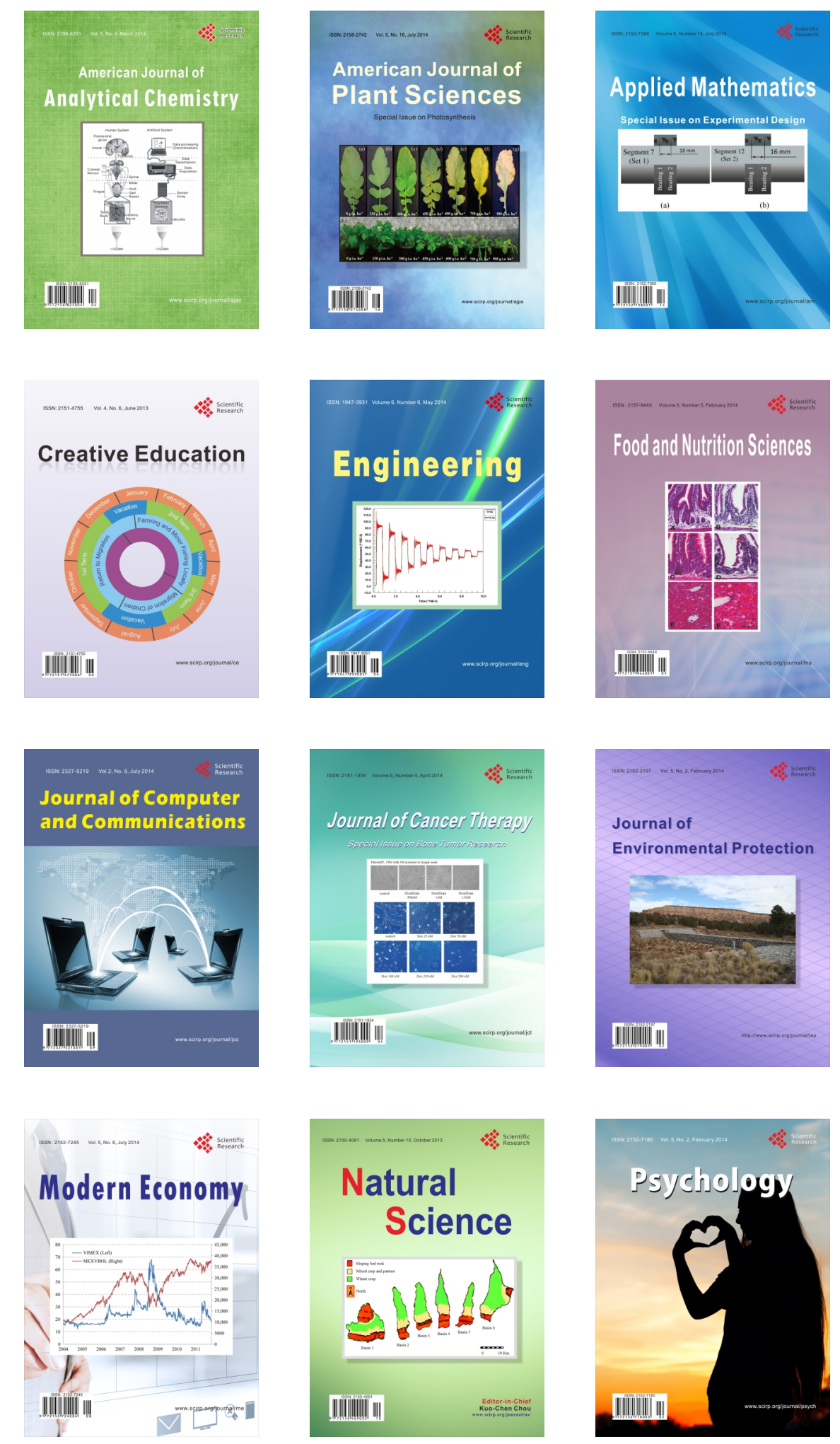